\title{
GRAVITY AND MAGNETIC SIGNATURE OF THE TRANSBRASILIANO LINEAMENT IN THE EAST-CENTRAL PORTION OF THE PARNAÍBA BASIN, NORTHEASTERN BRAZIL
}

\author{
Thuany Patrícia Costa de Lima' ${ }^{1}$ Emanuel Ferraz Jardim de Sá2, Fernando Antonio Pessoa Lira Lins², \\ Alex Francisco Antunes $^{2}$ and José Antônio de Morais Moreira ${ }^{3}$
}

\begin{abstract}
The Transbrasiliano Lineament (TBL) corresponds to a NE-trending mega shear zone of late Neoproterozoic age with an extensive segment underneath the Parnaíba Basin (northeastern Brazil); the Eopaleozoic to Mesozoic section of the basin evidence the lineament's brittle reactivation events. This paper presents a case study of TBL in the east-central portion of Parnaíba Basin with a special concern to the characterization of pre-Silurian grabens in the basement. The approach involves the interpretation of potential field data and seismic reflection line based on a plastic dextral transcurrent mega shear zone model. The gravity anomaly belts display a curvilinear shape joining the NE trend of the TBL, in accordance to a dextral S-C pair. A retrogressive stage with narrower ductile-brittle dextral structures controlled the opening of pull-apart grabens. Magnetic anomalies seem to be related to these late structures. The integration of the map analyses, seismic interpretation and 2D gravity modeling led to the conclusion that the sources causing the gravity and magnetic anomalies in the basin result from mass variations related to anisotropies of the crystalline basement and crustal heterogeneities, such as granite plutons, metasedimentary belts, shear zones and pre-Silurian grabens. The delimitation of grabens underneath the Parnaíba Basin suffers severe restrictions when solely interpreted based on potential field data.
\end{abstract}

Keywords: gravity forward modeling, Transbrasiliano Lineament, magnetic anomaly.

RESUMO. 0 Lineamento Transbrasiliano (LTB) corresponde a uma megazona de cisalhamento com direção NE, de idade Neoproterozoica, com um extenso segmento subjacente à Bacia do Parnaíba; a seção Eopaleozoica a Mesozoica da bacia evidencia seus eventos de reativação. Este trabalho aborda o LTB na porção centroleste da Bacia do Parnaíba, com especial atenção à caracterização de grabens pré-Silurianos do embasamento. A abordagem envolve interpretações de dados de métodos potenciais e de linha sísmica de reflexão baseadas em um modelo de megazona de cisalhamento plástica transcorrente dextral. As faixas de anomalias gravimétricas exibem uma geometria curvilínea, aproximando-se em direção ao trend NE do Lineamento Transbrasiliano, em consonância a um par S-C dextral. Um estágio retrogressivo com estruturas dúcteis-frágeis mais estreitas controlaram a abertura de grabens pull-apart. As anomalias magnéticas imageam essas estruturas tardias. A integração da análise de mapas de anomalia, interpretação sísmica e modelagem gravimétrica 2D permite concluir que as fontes causadoras das anomalias gravimétricas e magnéticas na bacia resultam de variações de massa relacionadas às heterogeneidades crustais e às anisotropias do embasamento cristalino, tais como plútons graníticos, faixas de metassedimentos e zonas de cisalhamento, com contribuição subordinada dos grabens pré-Silurianos. A delimitação desses grabens subjacentes à Bacia do Parnaíba sofre severas restrições quando interpretadas unicamente com base nos dados de métodos potenciais.

Palavras-chave: modelagem gravimétrica direta, Lineamento Transbrasiliano, anomalia magnética.

\footnotetext{
1 Universidade Federal do Rio Grande do Norte, Programa de Pós-graduação em Geodinâmica e Geofísica, Campus Universitário Lagoa Nova, Caixa Postal 1596, 59078-970 Natal, RN, Brazil. Phone: +55(84) 3342-2237-E-mail: thuanypatricia@gmail.com

2Universidade Federal do Rio Grande do Norte, Laboratório de Geologia e Geofísica do Petróleo, Departamento de Geologia, Campus Universitário Lagoa Nova, Caixa Postal 1678, 59078-970 Natal, RN, Brazil. Phone: +55(84) 32153683, ramal 317 -E-mails: emanuel@ccet.ufrn.br; flins@geologia.ufrn.br; alex@geologia.ufrn.br 3 Universidade Federal do Rio Grande do Norte, Laboratório de Geofísica Aplicada, Departamento de Geofísica, Campus Universitário Lagoa Nova, 59078-970 Natal, RN, Brazil. Phone: +55(84) 3342-2237, ramal 606 - E-mail: moreira@geofisica.ufrn.br
} 


\section{INTRODUCTION AND OBJECTIVES}

The Parnaíba Basin is located in the western region of northeast Brazil with approximately $600,000 \mathrm{~km}^{2}$ area and geographically includes states of Piauí, Maranhão, Pará, Tocantins and Ceará. It is classified as an intracratonic basin of syneclysis (or sag) type, with an elliptical surface geometry. The basin contains sedimentary sequences from Silurian to the Late Cretaceous and its igneous suites are related to Early Jurassic and Early Cretaceous events (Fig. 1).

The basement of Parnaíba Basin contains an extensive segment of the Transbrasiliano Lineament (TBL; Fig. 1), which is defined by Schobbenhaus (1975) as an intensely faulted zone that crosses Brazil from the northeast to central-west and continues towards the territories of Paraguay and Argentina. The TBL extends from the northwest of Ceará State where it is locally denoted as Sobral-Pedro II Lineament, crosses Parnaíba Basin (expressed at the surface by a post-Silurian brittle overprinting) and continues through the states of Tocantins and Goiás up to the northwest border of Paraná Basin. Along this trend, it is clear the change in its structural signature and age of deformation that are present either in the Precambrian crystalline basement or in the postOrdovician sedimentary cover. Graben structures filled with preSilurian deposits (eg. Jaibaras Graben), structural highs and depositional axes of the basin Paleozoic units were interpreted as being controlled by the TBL (Nunes, 1993).

Several authors have used potential field methods (Nunes, 1993; Sousa, 1996; Romeiro, 2014; de Castro et al., 2013, 2016; Pedrosa Jr et al., 2015, 2016) and seismic data (Morais Neto et al., 2013; Arêas et al., 2013; Daly et al., 2014; de Castro et al., 2016; Antunes et al., 2015) in order to detail the tectonicstructural framework of the basin, including the occurrence of preSilurian late-Brasiliano molasse-filled grabens. This paper offers new insights on the interpretation of geophysical anomalies observed in gravity and magnetic anomaly maps of Parnaíba Basin, with emphasis on its central eastern $69,000 \mathrm{~km}^{2}$ area (Fig. 1).

\section{METHODS AND RESULTS}

\section{Geophysical Data}

This work involved the application of interpretation techniques for potential methods data (gravity and magnetic), and 2D gravity forward modeling constrained in the light of one seismic reflection section (ID 0295-0006) with 190 km length (Fig. 2). Joint analysis of potential field data and seismic data was also studied by Morais Neto et al. (2013) and Arêas et al. (2013). Gravity and magnetic data used in this work were obtained from the project "Levantamentos Aerogeofísicos da Bacia do Parnaíba" financed by ANP. The average flight height was $800 \mathrm{~m}$ above the ground.
Figure 2 illustrates the location of the well used to convert the seismic line from time to vertical depth scale. The gravity model response is based on the methods of Talwani et al. (1959) and Talwani \& Heirtzler (1964), and the algorithms used to perform the modeling procedures are disclosed by Won \& Bevis (1987). Oasis Montaj (v7.0.1) and GM-SYS software (NGA, 2004) from Geosoft Inc. were used for data processing, generating geophysical anomalies maps, and gravity modeling.

\section{Potential Field Data Maps}

The results of interpretations were based on Bouguer, residual Bouguer, magnetic and reduced to pole magnetic anomaly maps (Fig. 2). The residual Bouguer anomaly was obtained using a Gaussian filter where the chosen cutoff was 0.007 cycles $/ \mathrm{km}$, corresponding to $140 \mathrm{~km}$ of wavelength. Gravity and magnetic data points were interpolated by the minimum curvature method of the RANGRID program in a square grid of $1.5 \mathrm{~km}$.

Trends of positive anomalies were interpreted from the residual Bouguer anomaly (Fig. 3A) which displays an outstanding curvilinear pattern that changes from N-S to NE-SW in the further south, the latter dominant along the main trend of TBL (white arrows in the figure). The width of the anomaly belts is consistent with their interpretation as structurally controlled compositional contrasts in the Precambrian basement. The location and orientation of these belts correlate well to a dextral transcurrent mega shear zone with S-C domains (Fig. 3C), thus expressing the TBL signature. Four major anomalies inside the study area were highlighted in the map (Fig. 3A and $3 \mathrm{~B}$ ) and interpretations are discussed throughout the text. Straighter and narrower magnetic trends (in the reduced to the pole magnetic anomaly; Fig. 3B) were interpreted in the centre of the anomalies (most cases) and along rectilinear segments in the edge of some paired anomalies, the latter (dashed black lines) being associated with structural discontinuities (eg. late stage of low temperature shear zones or brittle faults active during the TBL cooling and exhumation; Fig. $3 \mathrm{C}$ ).

\section{Seismic Data}

The seismic section was roughly converted from vertical time scale (about 4 seconds of two-way travel time) to depth scale. This approach offered depths of seismic reflectors that were used as prior information to the geological model.

For the conversion it was used a time-depth table obtained from a sonic profile of a well located $90 \mathrm{~km}$ distance from the seismic line, in the northeast corner of the study area. Time and depth data provided by the well were plotted in a graph in order 


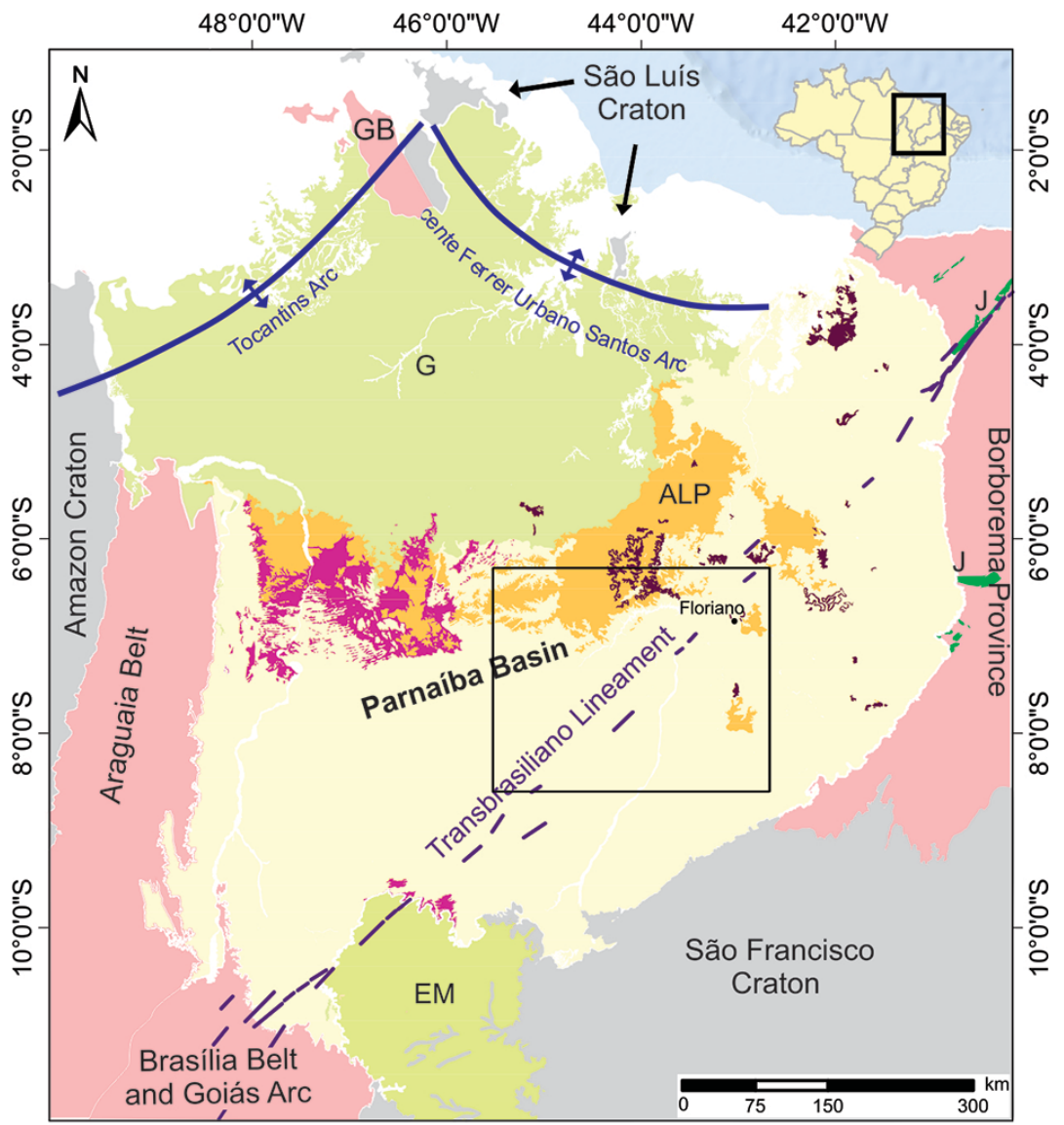

\section{Legend}
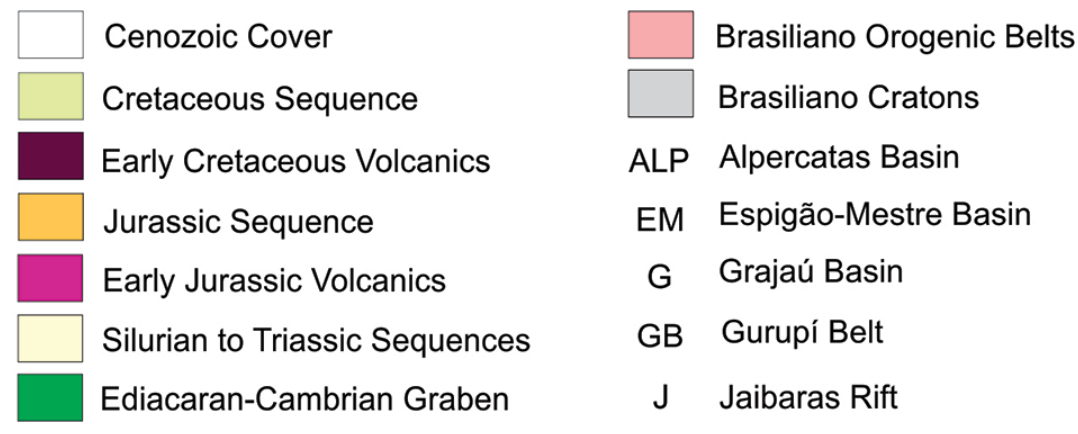

Figure 1 - Simplified geological map of Parnaíba Basin and surrounding Precambrian basement (modified after Cunha, 1986; and Schobbenhaus et al., 2004). The trace of the NE-trending TBL was interpreted by Lima (2015) through SRTM images. The study area is shown in the polygon. Major depositional sequences follow the proposals of Góes (1995) and Vaz et al. (2007).

to find an equation that sets the adjustment curve of the obtained points. The relationship between these variables is illustrated in Figure 4.

For the obtained equation ( $y=384.7 x^{2}+1224.8 x-$ 89.662), the $X$ variable corresponds to two-way travel time values of each mapped horizon in the seismic section, and $Y$ corresponds to values in depth.

\section{D Gravity Forward Modeling}

The residual component of the Bouguer gravity field was used for modeling sources at upper crustal levels. The purpose of the forward modeling was to test geological hypotheses for the subsurface structural framework seeking to demonstrate compatibility between the gravity profiles and possible sources of anoma- 

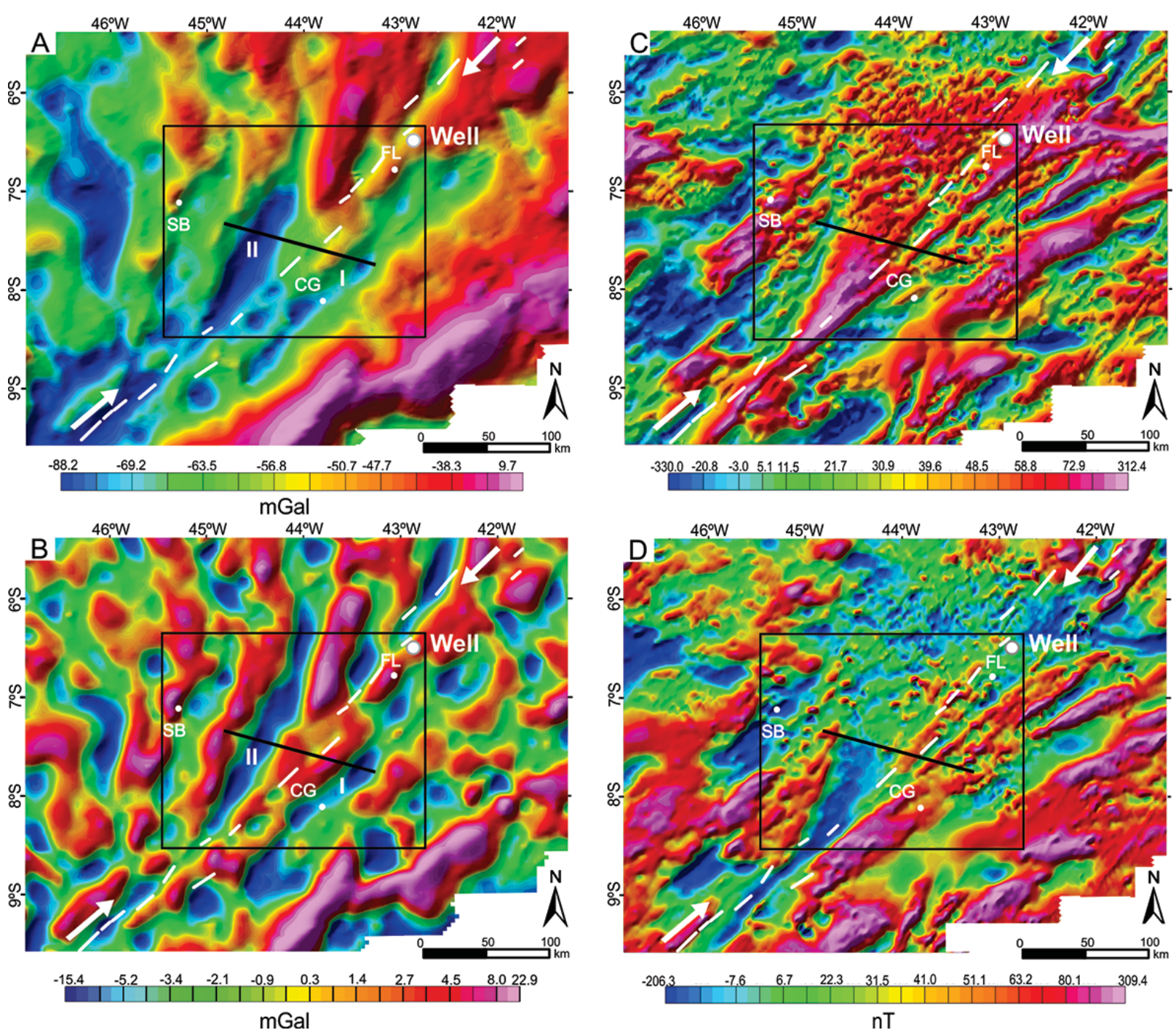

Figure 2 - Gravity and magnetic anomaly maps. Study area delimited by the black frame, while the expanded polygon will be referred along the text as the regional area; A) gravity Bouguer anomaly; numbers I and II refer to the location of interpreted anomalies B) residual Bouguer anomaly; C) magnetic anomaly; D) reduced to the pole magnetic anomaly. All figures include the location of the selected seismic section (black line in the center of the frame) that crosses NE-SW oriented gravity anomalies along the Transbrasiliano Lineament, and the well used to control its interpretation. The dashed white lines represent post-Silurian brittle lineaments interpreted from radar imagery and geological maps (as in Fig. 1). White arrows in all maps indicate an approximate location of the TBL main displacement zone (the C volume in shear zone terminology). The acronyms FL, SB and CG refer to the cities of Floriano, Sambaíba and Colônia do Gurguéia, respectively.

lies that are constrained by seismic interpretation and geological surface data.

The interpretation of seismic sections in this and in other studies previously referred indicates that the Paleozoic and Mesozoic sections of the basin have layers with lateral uniform extent, not being affected by post-Silurian faults. In Figure 5, two horizons related to striking reflectors were mapped and correlated with interfaces of stratigraphic units that occur in the Parnaíba Basin, following the stratigraphic chart by Vaz et al. (2007). One horizon (in yellow) corresponds to the top of the Pre-Silurian Sequence (correlated to the Jaibaras Group, in NE Ceará State, or the Precambrian crystalline basement if the former is absent). This horizon also coincides with the base of the Silurian Sequence, the Serra Grande Group. The corresponding reflector is positioned around 1.4 seconds and displays a positive contrast of acoustic impedance highlighted in black, which reflects a change of rock units of lower to higher impedance. A second reflector, mapped at 1.7 seconds, was interpreted as the top of the Precambrian 

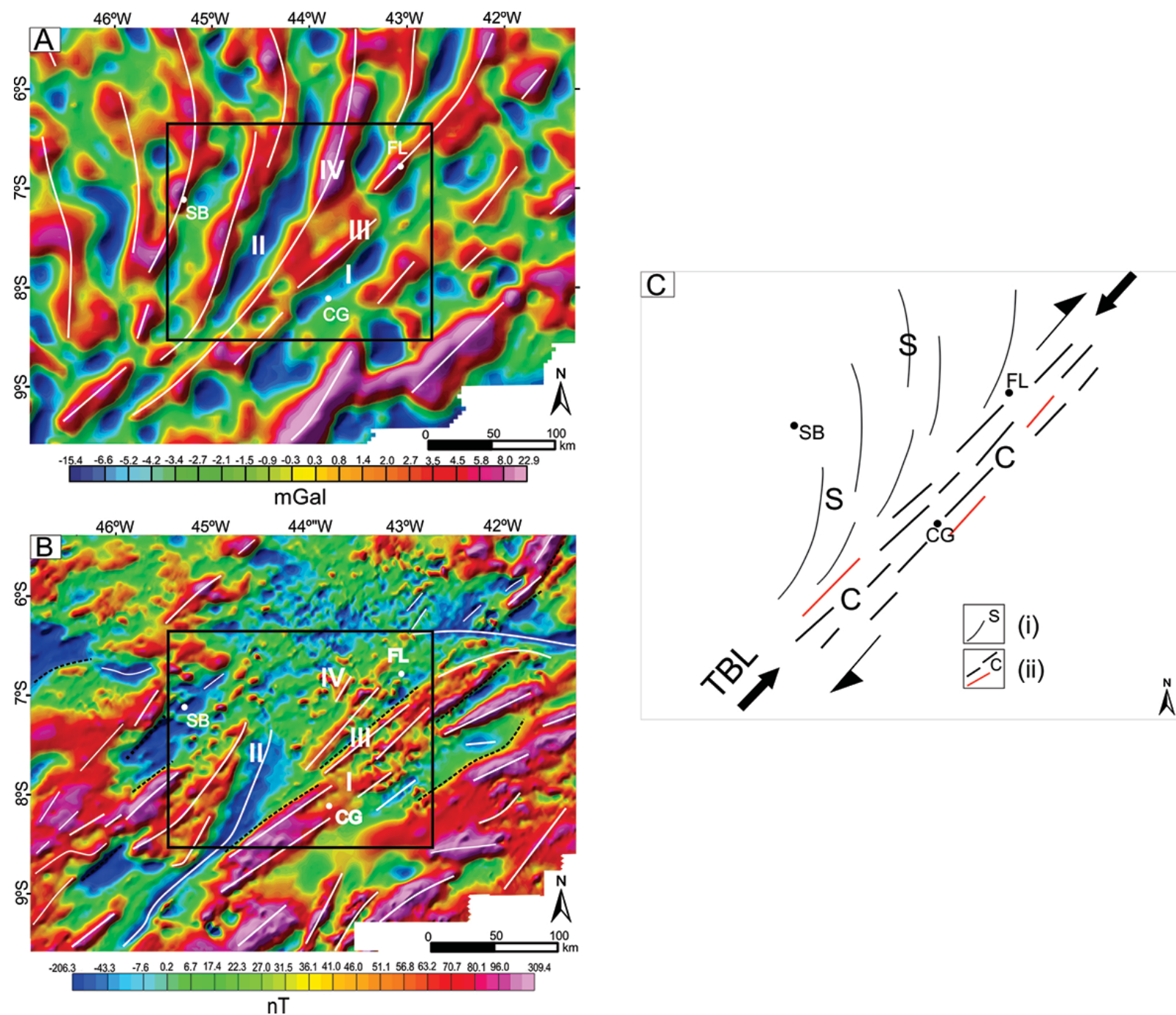

Figure $3-$ A) Residual Bouguer anomaly with interpretation of trends of positive gravity anomalies in white lines; B) reduced to the pole magnetic anomaly with interpretation of some magnetic trends in white lines (axes of positive and negative anomalies) and black dashed lines (edges of some paired anomalies); C) S-C structural domains associated to a dextral transcurrent mega shear zone; (i) refers to ductile shear zone of high temperature stage and (ii) refers to ductile-brittle shear zone of lower temperature stages of TBL. The acronyms FL, SB and CG refer to cities of Floriano, Sambaíba and Colônia do Gurguéia, respectively. I to IV locate anomalies to be discussed in the text.

Basement, which may also coincide with the base of the PreSilurian sequence or, in case of absence of the latter, the base of the Serra Grande Group. The seismic reflectors display a parallel configuration in the post-Ordovician section and/or divergent configuration in the Pre-Silurian section.

\section{DISCUSSIONS}

In terms of the geological-geophysical interpretation of the regional framework of TBL, this work is grounded:

(i) in the concept and geometry of shear zones; (ii) in the exposures of TBL in the Precambrian basement at the NE and SW borders of Parnaíba Basin.

The structural model (Fig. 3C) considers a crustal-scale displacement zone (rooted in the lithospheric mantle) where the southeast portion consists of a wide and straight band (the C volume) defined by high temperature, amphibolite to granulite facies and mylonite belts. This volume is associated with the NEtrending plastic shear zone of the TBL and its width reaches an order of hundred kilometers, as deduced from CPRM maps and radar imagery of the basin eastern and southwestern borders. 


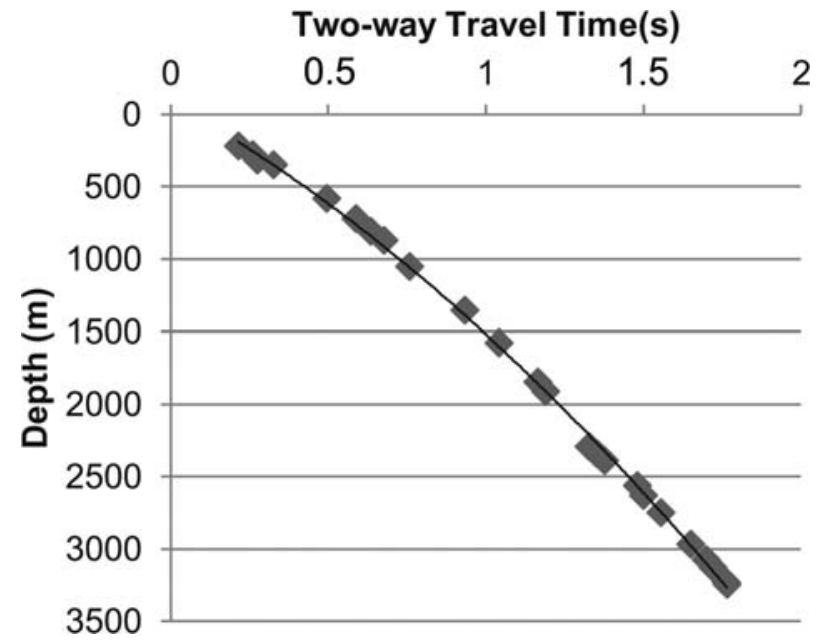

Figure 4 - Graph of two-way travel time versus depth.

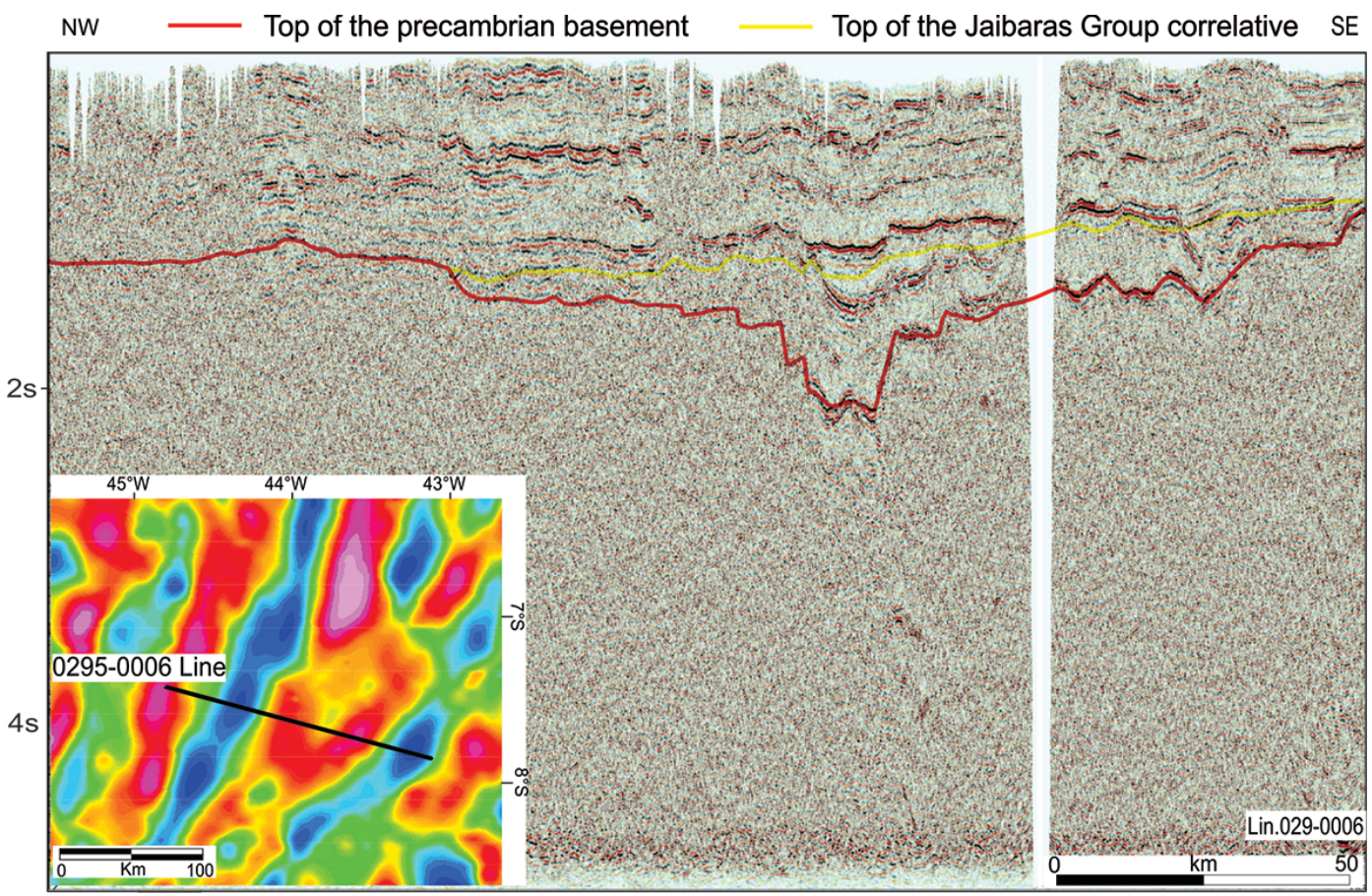

Figure $\mathbf{5}$ - Interpretation of horizons in the seismic line; the inset shows the location of the seismic line in the residual Bouguer anomaly map. Some of the younger outstanding reflectors are probably associated to basic volcanic sills intruded in the Paleozoic section.

The adjacent S-surfaces (flattening planes to the northwestern in Fig. 3C) control the geometry of geological bodies pretectonic or syntectonic to the shear zone and display a characteristic sigmoidal pattern consistent with the dextral kinematics of the TBL. In its expression at a median level of the crust contemporaneous or later uplifted by tectonic exhumation and denudation, the shear deformation tends to focus along localized retrometamor- phic mylonite bands (low amphibolite to the green schist facies), closer one to the other (up to tens of kilometers) and still displaying the S-C pattern. In late stage of the exhumation process in shallower crustal sections, the displacement surfaces correspond to localized ductile-brittle structures which may control the opening of pull-apart or oblique grabens with rectilinear or rhombohedral shapes. That represents the final expression of the shear 
zone kinematics, and in the case of TBL, it would correspond to the development stage of the pre-Silurian graben exposed at the eastern border of Parnaíba Basin.

\section{Analysis of Gravity and Magnetic Anomaly Maps}

The pattern the gravity anomalies are interpreted according to the configuration of N-S to NE-trending compositional belts associated to distinct petrostructural units, such as granite plutons, metasedimentary rocks and higher density gneissic complexes. These belts constitute mega tectonic slices and the S-C pair configuration (Fig. $3 \mathrm{C}$ ) probably has some influence from the N-S trends of the Araguaia Belt (north of $7^{\circ}$ to $6^{\circ} 30^{\prime} S$ parallels), which is considered slightly older. These structures were overprinted (and a new fabric was generated) by the dextral strike-slip kinematics of the TBL in its higher temperature stage (580-550 Ma; Ganade de Araújo et al., 2013) during the Brasiliano orogeny; this interpreted chronological evolution is compatible with the scenario proposed by these authors.

Pre-Silurian grabens display variable gravity and magnetic signatures, mainly due to the thickness of the sedimentary cover and abundance of volcanic intercalations (Pedrosa Jr et al., 2016). The interplay between different basement sources, deeper or shallower, and their own heterogeneity represents a major difficulty when interpreting these grabens (or other kinds of pre-Silurian basins; Miranda, 2017) solely based on potential methods data.

Magnetic anomalies (Fig. 3B) correspond to lower temperature (ductile-brittle) strike-slip dextral shear zones NE-SW oriented, like the ones that border Jaibaras and Cococi graben in Northwest Ceará (Cacama et al., 2015; Pedrosa Jr et al., 2016).

\section{Interpretation of Selected Potential Field Anomalies}

The Bouguer anomaly (Fig. 2A) highlight two gravity lows striking NNE to NE (labeled as I and II in this figure), which become particularly clear in the residual Bouguer anomaly (Figs. 2B and $3 \mathrm{~A}$ ) and when the area covered by the data is expanded (previously defined as the regional area in Fig. 2). The first anomaly (I) is located in the southeastern portion of the study area (Fig. 3A) and presents a rectilinear shape, continuing beyond the polygon limits and being interpreted as part of the gravity signature of Transbrasiliano Lineament along a NE-trending mylonite belt (the C volume; Fig. 3C). Located further to the NW, anomaly (II) presents a curvilinear geometry characteristic of S-surfaces controlled belts that means a contractional tectonic environment that precludes graben structures as the anomaly source, as interpreted in former contributions (Nunes, 1993; Cordani et al., 2009), changing from NNE to NE strike closer to the main LTB mylonite belt. These anomalies (I and II) can be explained by the presence of less dense bodies in the crystalline basement of the basin (eg. granitic or metasedimentary rocks) and additionally for the rectilinear (I) anomaly, a pull-apart graben (or late extensional reactivation of the LTB trend) filled mainly with sedimentary rocks. The adjacent gravity highs (II and III) correspond to higher density rocks, such as high grade orthogneisses and intermediate to acid plutons, or even metavolcanic-rich supracrustal sequences. This pattern of gravity lineaments is reproduced further east of Parnaíba Basin, in the terrains of the Borborema Province (Oliveira, 2008).

In the SE corner of the regional area (north of $9^{\circ}$ to $8^{\circ} \mathrm{S}$ parallels; Fig. 3A) and parallel to the SE border of the Parnaíba Basin, there is a major elongated positive anomaly also striking NE, interpreted as the gravity signature related to a Brasiliano collisional event in the NW margin of the São Francisco Craton (Oliveira, 2008).

The reduced to the pole magnetic anomaly (Fig. 3B) is also characterized by anomalies with NE-SW preferred orientation, more rectilinear when compared to the residual gravity anomalies. The continuous white traces in this map are interpretations of the magnetic trends along the central axes of the anomalous magnetic bodies. Locally, some trends were added (dashed black traces) along straight segments on the edges of anomalies trending NE which may correspond to discontinuities (faults or ductilebrittle shear zones) delimitating blocks with contrasting magnetic signatures. The (II, IV) and (I, III) anomalies repeat the angular relationship described before for dextral S-C pairs. However, northwestern of II and IV anomalies the orientation of the magnetic anomaly is different from that of the gravity trends and still not fully understood; an $\mathrm{E}-\mathrm{W}$ linear anomaly can also be noticed in the NE quadrant of the map (east of $43^{\circ} \mathrm{W}$ to $41^{\circ}$ meridians). This configuration is again attributed to sources contained in the heterogeneous basement (plutons, metasedimentary rocks and high grade gneisses), in part delimited by more rectilinear and discrete structures (compared to those highlighted in the residual Bouguer map) and probably younger and of lower temperature (as regards to the ones of the gravity trends), following the retrometamorphic evolution of TBL. It is also possible that some isolated magnetic anomalies correspond to igneous bodies of late Brasiliano or Mesozoic age. The configuration of these discrete lineaments in the basement can be interpreted in analogy to the Riedel fractures model, considering steep dipping planes and a sub-horizontal movement section, as expected for a dextral strike-slip kinematics during a low temperature stage in the TBL evolution. 


\section{D Gravity Modeling and Seismic}

The presented models consider different sources of anomalies with the purpose of evaluating the inference of graben structures on the gravity signature of the basin. This contributes to the evaluation of eventual control on the basin (mechanical vS. thermal) subsidence processes, as proposed by Oliveira (2008).

The analysis of the gravity forward models was divided into in three steps. The first (Fig. 6A) sought to examine the gravity response of the basin architecture in which the flat-lying undifferentiated Paleozoic sequences overly (through an angular unconformity or non conformity) graben structures interpreted as cor- related to the Jaibaras Group. These grabens are considered to be of Ediacaran to Cambrian age and are part of the Precambrian to Cambrian basement of the basin. The residual gravity anomaly calculated for such geological model does not correspond to the observed residual anomalies (Fig. 6A). Furthermore, the main depocenter overlies a large positive anomaly (albeit with a smooth possibly superimposed negative anomaly) with a broader wavelength, sourced at the Precambrian basement. Well developed negative anomalies sideways to the positive one do not correspond to graben depocenters, except for a minor one at the ESE end of the seismic line. These features show that other sources
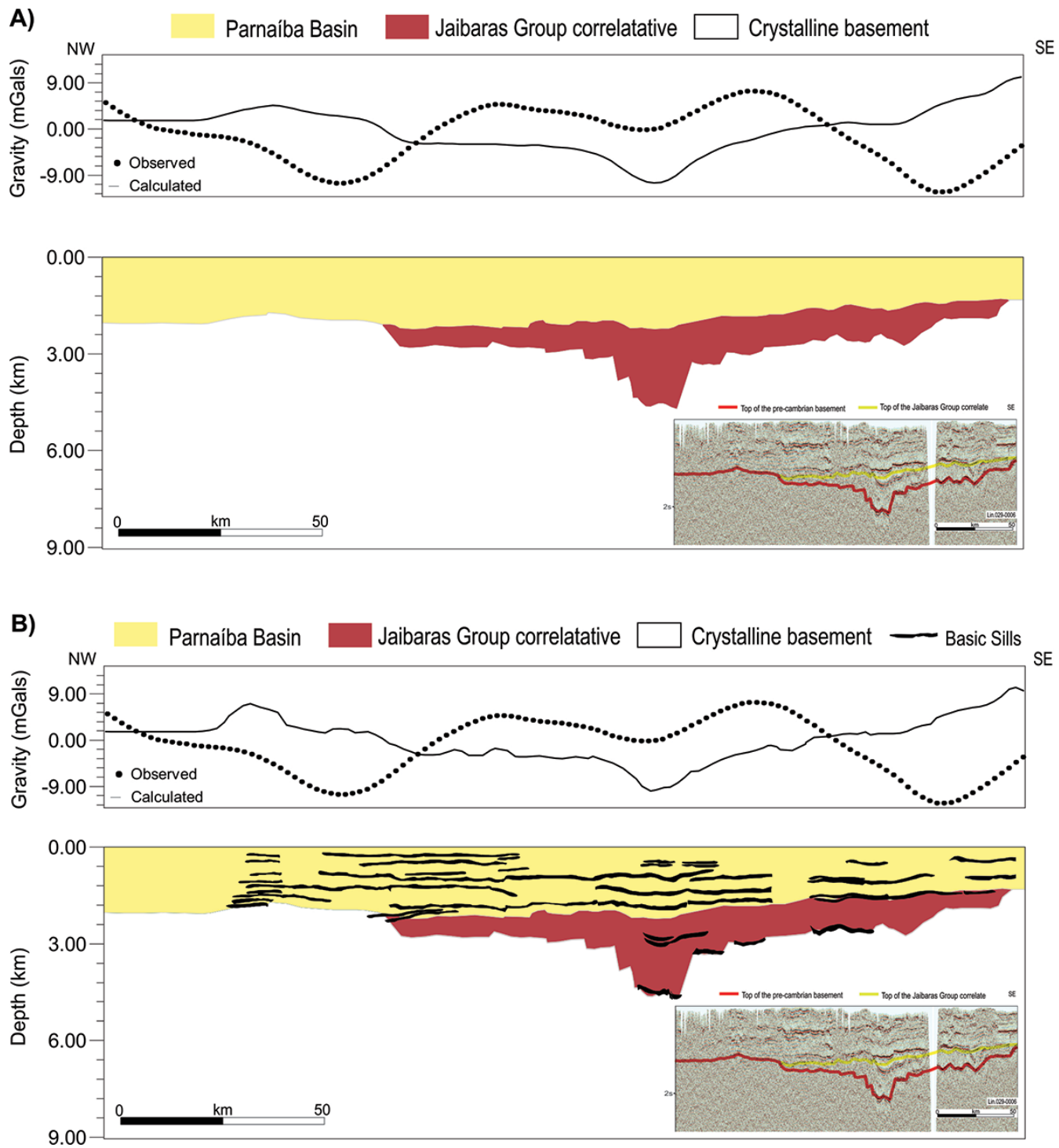

Figure 6 - A) Gravity model considering the Paleozoic sedimentary section of the basin and an underlying pre-Silurian graben; B) gravity model considering, apart from the Paleozoic section of the basin, the occurrence of basic Mesozoic sills. The density values assigned in the gravity modeling were $2.44 \mathrm{~g} / \mathrm{cm}^{3}$ to the basin sedimentary section, $2.60 \mathrm{~g} / \mathrm{cm}^{3}$ to Jaibaras Group correlative sequences, $2.96 \mathrm{~g} / \mathrm{cm}^{3}$ to the basic igneous rocks and $2.74 \mathrm{~g} / \mathrm{cm}^{3}$ for the Precambrian basement. The inset shows the interpreted horizons of the seismic section. 
inside the Precambrian basement are interfering in the gravity signature of such grabens.

The occurrence of younger basic sills (of Early Jurassic to Early Cretaceous age; Vaz et al., 2007) are expected in the geological context of the basin and are suggested by remarkable seismic reflectors (Fig. 6B). Thus, it seemed appropriate to test their influence in the gravity anomalies, even though their horizontal tabular shapes (sills and lacoliths) do not match with the belt geometry of the anomalies. In this second stage of modeling, basic sills were added in the Paleozoic section of the basin, as well as in the underlying graben structures interpreted along the most significant high amplitude reflectors observed (Fig. 6B). It was found that these shallow sources, even in extrapolated volumes, do not affect the calculated gravity anomalies and therefore do not majorly contribute as a source.

In addition to the features discussed in preceding sections, these results support the assumption that the NE to NNE trending gravity anomalies, as well as most of the magnetic ones, are associated to heterogeneities in the Precambrian crystalline basement, as in the case of curvilinear belts. Eventually, the rectilinear NE-trending ones are associated to pre-Silurian graben laterally juxtaposed by intrusive contacts or brittle-ductile shear zones. Main source types to be considered are less dense granitic, metasediments and sedimentary rocks (the volcanic component inside Jaibaras-type grabens appears to be subordinate), higher density gneiss-granulite blocks or (meta)basic rocks. In the influence area of TBL (width estimated to be at least $100 \mathrm{~km}$, based on the outcropping mylonite belts and the wavelength of the NE to NNE anomaly bands; Fig. $3 \mathrm{~A}$ and $\mathrm{SC}$ ), such bodies should have steep dipping flat shapes elongated at NE to NNE trends, reflecting the strain associated with the dextral strike-slip shear regime of TBL, reaching variable depths. These sources are certainly interfering in anomalies caused by shallower sources, such as those expected from graben structures.

In a third modeling step, the occurrence of such intrabasement sources was tested. The model in Figure 7A assumes the existence of granite plutons and/or keels of Precambrian metasediments as the main source of the anomalies, which would be responsible for elongated low gravity features (such as negative anomalies I, II) in the residual gravity anomaly (Fig. 3A).

The model in Figure 7B assigns the sources of gravity highs to denser amphibolite to granulite facies gneiss belts, reaching depths up to $17 \mathrm{~km}$. The occurrence of small granite plutons was also considered in this model.

Another possibility considered for intra-basement source would be related to the post-Silurian evolution of the basin. The occurrence of dense bodies at deeper crustal levels representing events of basic-ultrabasic intra or underplating are correlated to the shallow magmatism of Early Jurassic to Early Cretaceous age observed in the basin. Such magmatic bodies were modeled by Martins et al. (2007). Daly et al. (2014) identified striking seismic reflectors at $20 \mathrm{~km}$ depth, to the west of the city of Teresina (Piauí State). These reflectors may be associated with rocks whose acoustic impedance is quite different from the adjacent crystalline rock, such as large sills and/or magmatic chambers. This interpretation do not explain the NE to NNE trending positive gravity anomaly belts which are better interpreted as a signature imprinted during earlier high temperature deformation stage of Brasiliano age. Models were tested interpreting younger sources, considering a denser basic/ultrabasic body at $20 \mathrm{~km}$ depth (Fig. 8). Less dense granite plutons and/or metasedimentary keels are also incorporated into this model in order to adjust the adjacent low gravity anomalies along the profile.

\section{CONCLUSIONS}

The integration of potential field data constrained by seismic interpretation and an adequate tectonic-structural model led to a qualitative interpretation concluding that the gravity anomaly highlights the structural features of the high temperature stage (a plastic shear zone) of the Transbrasiliano Lineament in the basement of Parnaíba Basin. Its signature corresponds to large and elongated bands arranged as a dextral S-C pair, in accordance to the basement exposures bordering the basin. However, gravity data is not effective, by itself, to unambiguously characterize younger structures such as the pre-Silurian grabens (or even Mesozoic basic rocks) identified by seismic interpretation. The section of rocks equivalent to Jaibaras Group displays discrete gravity anomalies that suffer the interference from structured deeper sources.

The pattern of shorter wavelength in magnetic anomalies can be correlated to a lower temperature evolutionary stage (with ductile-brittle behavior) of TBL, resulting in more discrete and rectilinear NE-trending structures in the subsurface.

\section{ACKNOWLEDGEMENTS}

This work was supported by the project "Geologia e Sistemas Petrolíferos da Bacia Intracratônica do Parnaíba, Nordeste do Brasil" financed by Chevron Brasil and UFRN (PPGG/FUNPEC). The "Laboratório de Geologia e Geofísica do Petróleo - PPGG/UFRN" provided software and hardware facilities to develop this research. Authors acknowledge ANP for geophysical data conces- 


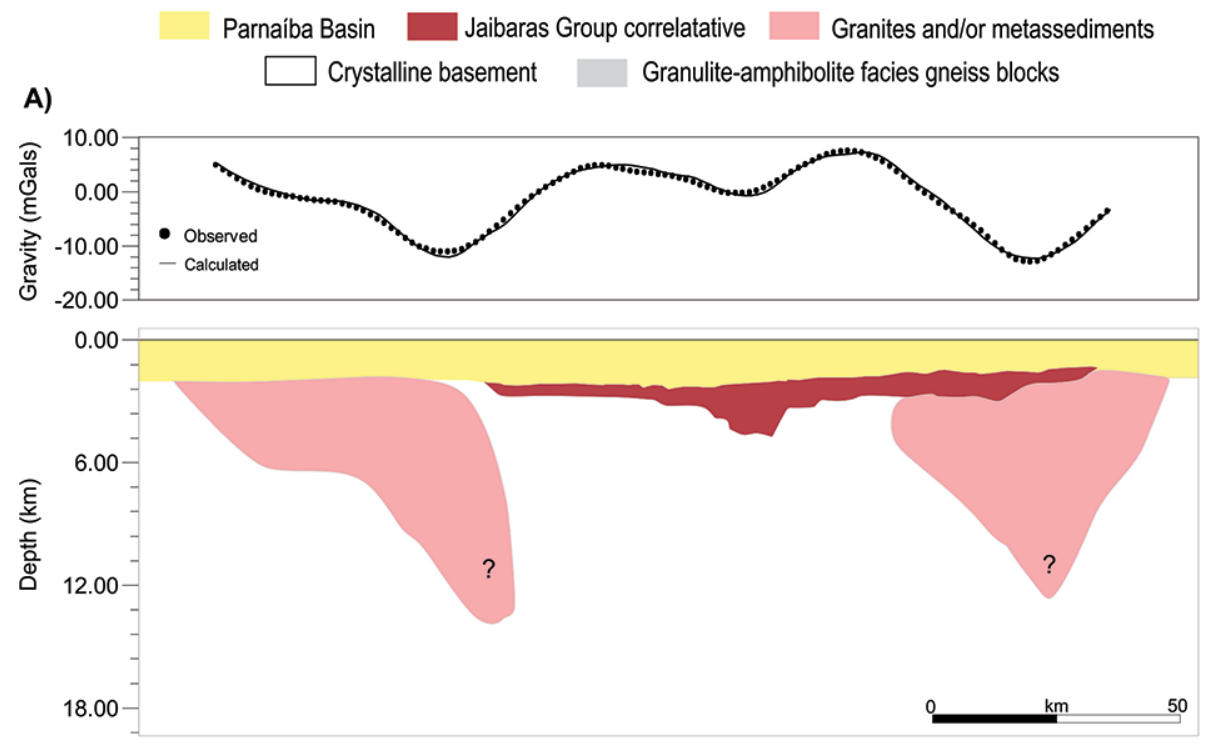

B)
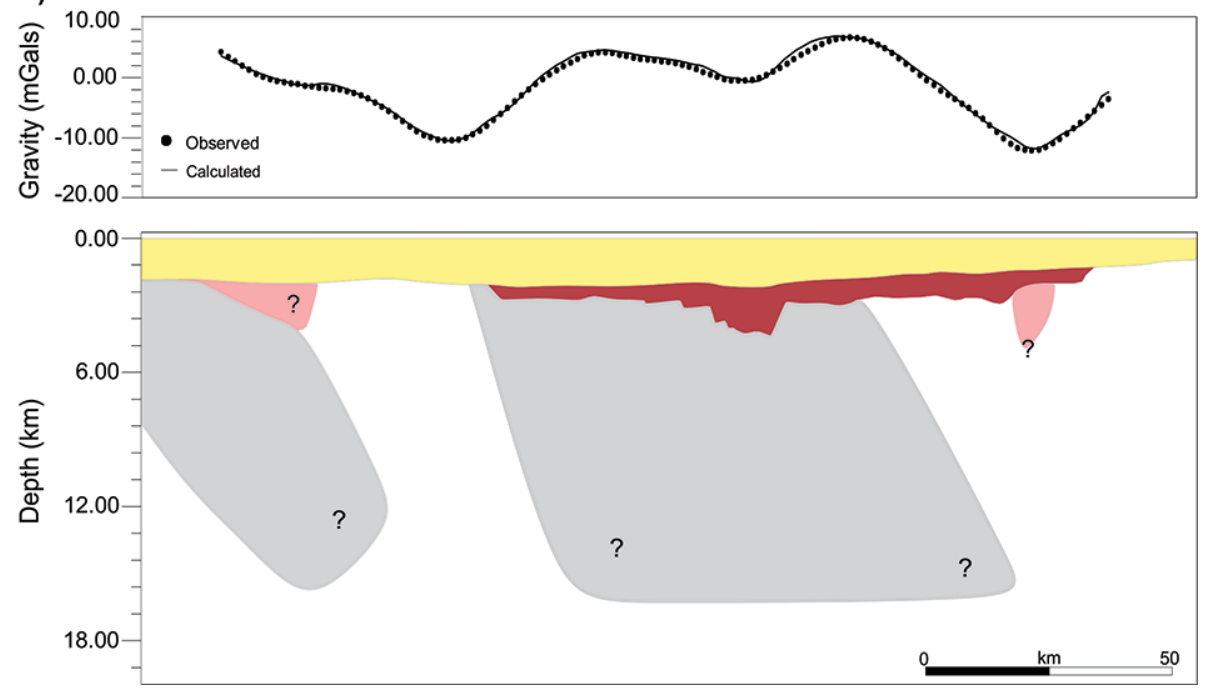

Figure 7 - Proposed models for configuration of heterogeneities in the Precambrian basement of Parnaíba Basin; A) model assuming the occurrence of granites and/or metassediments $\left(2.66 \mathrm{~g} / \mathrm{cm}^{3}\right)$ laterally to the positive gravity axis; B) model with denser granulite-amphibolitye facies gneiss blocks $\left(2.8 \mathrm{~g} / \mathrm{cm}^{3}\right)$ and small granite plutons sideways $\left(2.66 \mathrm{~g} / \mathrm{cm}^{3}\right)$.

sion. The first author acknowledges PRH22-ANP for the scholarship granted during her master's degree.

\section{REFERENCES}

ANTUNES AF, SILVA CCN, JARDIM DE SÁ EF, LIRA LINS FAP, CÓRDOBA VC, SOUSA DC \& ALVES DA SILVA FC. 2015. Expressão Sísmica do Lineamento Transbrasiliano na Porção Sul-Sudoeste da Bacia do Parnaíba. In: XXVI Simpósio de Geologia do Nordeste, Natal, Brazil, Palestras e Resumos - Boletim, 24: 192-192.

ARÊAS I, FERRARI AL, BEZERRA JR \& ETHIENNE A. 2013. A Influência
Tectônica do Lineamento Transbrasiliano na Bacia do Parnaíba. In: XIV SNET - Simpósio Nacional de Estudos Tectônicos. Cuiabá: SBGEO.

CACAMA MSJB, JARDIM DE SÁ EF, ALVES DA SILVA FC \& LINS FAPL. 2015. Assinatura estrutural e geofísica da Porção Norte (fronteira CearáPiauí) do Lineamento Transbrasiliano: reativação na Bacia do Parnaíba. Geologia USP. Série Científica, São Paulo, Brazil, 15: 67-81. D0l: http://dx.doi.org/10.11606/issn.2316-9095.v15i3-4p67-81.

CORDANI UG, BRITO NEVES BB \& THOMAZFILHO A. 2009. Estudo preliminar de integração do Pré-Cambriano com os eventos tectônicos das bacias sedimentares brasileiras (Atualização). Boletim de Geociências da Petrobras, 17(1): 205-219. 


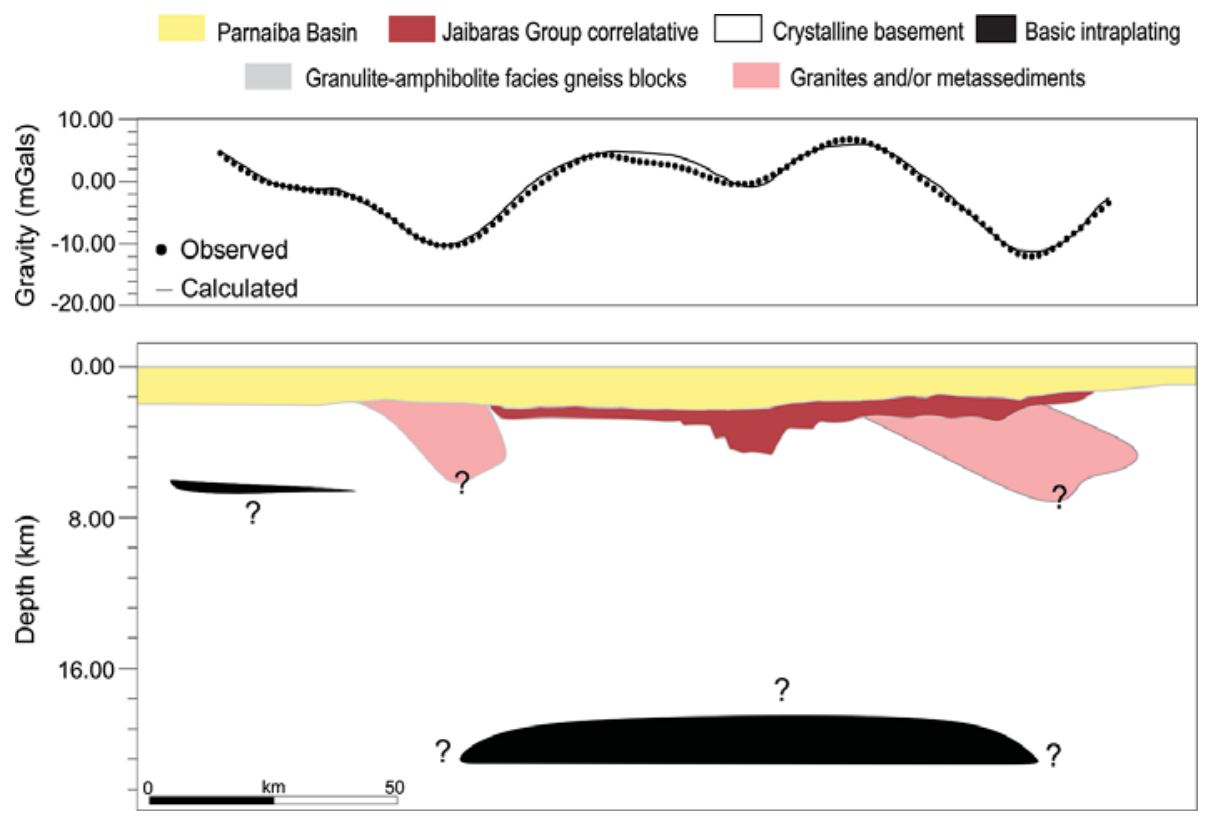

Figure 8 - Model for possible configuration of heterogeneities in the Precambrian basement of the Parnaíba Basin considering a denser basic intraplating $\left(3.0 \mathrm{~g} / \mathrm{cm}^{3}\right)$, in addition to granites and $/ 0$ r metassediments $\left(2.66 \mathrm{~g} / \mathrm{cm}^{3}\right)$.

CUNHA FMB. 1986. Evolução Paleozoica da Bacia do Parnaíba e seu Arcabouço Tectônico. Master Dissertation. Rio de Janeiro, Brazil: Instituto de Geociências, UFRJ. 107 pp.

DALY MC, ANDRADE V, BAROUSSE CA, COSTA R, McDOWELL K, PIGGOTT N \& POOLE AJ. 2014. Brasiliano Crustal Structure and the Tectonic Setting of the Parnaiba Basin of NE Brazil: Results of a Deep Seismic Reflection Profile. Tectonics, 33(11): 2102-2120. D0I:10.1002/2014TC003632.

DE CASTRO DL, FUCK RA, PHILLIPS JD, VIDOTTI RM, BEZERRA FHR \& DANTAS EL. 2013. Crustal Structure beneath the Paleozoic Parnaíba Basin revealed by Airborne Gravity and Magnetic Data, Brazil. Tectonophysics, 614: 128-145.

DE CASTRO DL, BEZERRA FHR, FUCK RA \& VIDOTTI RM. 2016. Geophysical evidence of pre-sag rifting and post-rifting fault reactivation in the Parnaíba basin, Brazil. Solid Earth, 7: 529-548.

GANADE DE ARAÚJO CEG, WEINBERG RF \& CORDANI UG. 2013. EXtruding the Borborema Province (NE-Brazil): a two-stage Neoproterozoic collision process. Terra Nova, 26(2): 157-168.

GÓES AMO. 1995. A Formação Poti (Carbonífero inferior) da Bacia do Parnaíba. Ph.D. Thesis. São Paulo, Brazil: Instituto de Geociências, USP. 204 pp.

LIMA TPC. 2015. Expressão Geofísico-Estrutural do Lineamento Transbrasiliano na Porção Central da Bacia do Parnaíba (Maranhão-Piauí). Master Dissertation on Geophysics. Natal, Brazil: Programa de PósGraduação em Geodinâmica e Geofísica, UFRN. 92 pp.
MARTINS JLP, RODRIGUEZ CO, CARVALHO FA \& WATANABE MD. 2007. Levantamentos Aerogeofísicos para a Identificação de Áreas com Ocorrência Potencial de Petróleo e Gás na Bacia do Parnaíba. TOMO VI: Área Parnaíba, 1, São Paulo, Brazil: Agência Nacional do Petróleo, Gás Natural e Biocombustíveis.

MIRANDA VN. 2017. Bacias pré-Silurianas na Porção centro-oeste da Província Parnaíba. Master Dissertation. Natal, Brazil: Programa de Pós-Graduação em Geodinâmicae Geofísica, UFRN. 93 pp.

MORAIS NETO JM, TROSDTORF JI, SANTOS SF, VASCONCELOS CS, MENEZES JRC, RIBAS MP \& IWATA SA. 2013. Expressão Sísmica das Reativações Tectônicas do Lineamento Transbrasiliano na Bacia do Parnaíba. In: XIV SNET - Simpósio Nacional de Estudos Tectônicos. Cuiabá, Brazil: SBGEO.

NGA. 2004. GM-SYS - Gravity/Magnetic Modeling Software: User's Guide version 4.9. Corvallis: Northwest Geophysical Associate, 101 pp.

NUNES KC. 1993. Interpretação Integrada da Bacia do Parnaíba com Ênfase nos Dados Aeromagnéticos. In: III International Congress of the Brazilian Geophysical Society, 152-157, Rio de Janeiro, Brazil: SBGf.

OLIVEIRA RG. 2008. Arcabouço Geofííico, Isostasia e Causas do Magmatismo Cenozóico da Província Borborema e de sua Margem Continental (Nordeste do Brasil). Ph.D. Thesis. Natal, Brazil: Programa de PósGraduação em Geodinâmica e Geofísica, UFRN. 415 pp.

PEDROSA JR NC, VIDOTTI RM, FUCK RA, OLIVEIRA KML \& CASTELO BRANCO RMG. 2015. Structural Framework of the Jaibaras Rift, Brazil, based on Geophysical Data. Journal of South American Earth Sciences, 58. D0I: 10.1016/j.jsames.2014.07.005. 
PEDROSA JR NC, VIDOTTI RM, FUCK RA, CASTELO BRANCO RMG, ALMEIDA AR, SILVA NV \& BRAGA LRC. 2016. Architecture of the intracontinental Jaibaras Rift, Brazil, based on geophysical data. Journal of South American Earth Sciences, 74: 27-40.

ROMEIRO MAT. 2014. Modelos Gravimétricos 2D da borda oeste da Bacia do Parnaíba e do seu Embasamento. Curitiba, Brazil: Programa de Pós-Graduação em Geologia, UFPR. 106 pp.

SCHOBBENHAUS C, CAMPOS DA, DERZE GR \& ASMUS HE. 1975. Texto Explicativo. Folha Goiás SD.22. In: SCHOBBENHAUSC (Coord.). Carta Geológica do Brasil Milionésimo. Escala: 1.000.000. Brasília: DNPM.

SCHOBBENHAUSC, GONÇALVES JH, SANTOS JOS, ABRAM MB, LEÃO NETO R, MATOS GMM, VIDOTTI RM, RAMOS MAB \& JESUS JDA. 2004. Carta Geológica do Brasil ao Milionésimo, Sistema de Informações Geográficas-SIG e 46 folhas na escala 1:1.000.000. Programa Geologia do Brasil. CPRM, Brasília, Brazil. 41 CD-ROMs.

SOUSA MA. 1996. Regional Gravity Modeling and Geohistory of the
Parnaiba Basin. Ph.D. Thesis. University of Newcastle upon Tyne, UK. $127 \mathrm{pp}$.

TALWANI M \& HEIRTZLER JR. 1964. Computation of Gravity Anomalies caused by Two Dimensional Structures of Arbitrary Shapes. Geological Sciences, 1(9): 464-480.

TALWANI M, WORZEL JL \& LANDISMAN M. 1959. Rapid Gravity Computations for Two-Dimensional Bodies with the Application to the Mendocino Submarine Fracture Zone. Journal of Geophysics Research, 64 : 49-59.

VAZ PT, REZENDE NGAM, WANDERLEY FILHO JR \& TRAVASSOSWAS. 2007. Bacia do Parnaíba. Boletim de Geociências da Petrobras, 15(2): 253-263.

WON IJ \& BEVIS M. 1987. Computing the Gravitational and Magnetic Anomalies due to a Polygon: Algorithms and Fortran Subroutines. Geophysics, 52(2): 232-238.

Recebido em 6 abril, 2017 / Aceito em 15 setembro, 2017

Received on April 6, 2017 / Accepted on September 15, 2017 